\title{
Hubungan Tingkat Sosial Ekonomi Dengan Pemahaman Gizi Orangtua
}

\author{
Fadlikhah Nur Rakhmania Sya'bana \\ PG-PAUD STKIP Modern Ngawi dan rachmania07@gmail.com \\ Mira Agustina \\ PG-PAUD STKIP Modern Ngawi dan mirhaagustina22@gmail.com
}

\begin{abstract}
Abstrak
Penelitian ini bertujuan untuk mengetahui hubungan tingkat sosial ekonomi terhadap pemahaman gizi orangtua yang dilaksanakan di TK Al-Ishlah Ngale Kecamatan Paron Kabupaten Ngawi. Jenis penelitian ini adalah kuantitatif. Besarnya sampel dalam penelitian ini berjumlah 30 orangtua. Penelitian ini merupakan penelitian korelasional dengan pendekatan kuantitatif untuk mengukur tingkat sosial ekonomi dan tingkat pemahaman gizi pada orangtua di TK Al-Ishlah Ngale. Teknik analisis dat yang digunakan adalah analisis korelasi pearson. Hasil penelitian menunjukkan bahwa terdapat hubungan yang lemah antara Tingkat Sosial Ekonomi dengan Pemahaman Gizi Orangtua hal ini ditunjukkan dengan perhitungan hasil SPSS yang bernilai 0,147.
\end{abstract}

Kata kunci : tingkat sosial ekonomi, pemahaman gizi orangtua

\section{PENDAHULUAN}

Sosial ekonomi adalah posisi yang di tempat individu atau keluarga yang berkenaan dengan ukuran rata-rata yang umum berlaku tentang kepemilikan kultural, pendapatan efektif, pemilikan barang dan partisipasi dalam aktivitas kelompok dari komunitasnya ( FS. Chapin (Kaare, 1989:26 ). Sedangkan menurut Melly G Tan, sosial ekonomi adalah kedudukan sosial ekonomi yang meliputi tiga faktor yaitu pekerjaan, pendidikan dan penghasilan. Setiap individu atau masyarakat pasti menginginkan status sosial ekonomi yang baik. Namun pada kenyataannya masih banyak indicidu atau masyarakat yang berstatus sosial ekonomi rendah.

Menurut Bome dan Walles ( dalam Myers, 1983: 220 ) individu yang memiliki tingkat ekonomi menengah keatas akan cenderung memiliki pola konsumsi yang berlebihandari pada mereka yang memiiki tingkat ekonomi menengah kebawah. Status sosial ekonomi sangat berpengaruh bagi pemenuhan kebutuhan hidup seharihari. Santrok (2007:282) mengemukakan sosial ekonomi adalah pengelompokan orang-orang berdasarkan kesamaan karakteristik pekerjaan, pendidikan dan ekonomi.

Gizi merupakan salah satu faktor penting yang menentukan tingkat kesehatan dan keserasian antara perkembangan fisik dan perkembangan mental. Tingkat keadaan gizi normal tercapai bila kebutuhan zat gizi optimal terpenuhi. Tingkat gizi seseorang dalam suatu masa bukan saja ditentukan oleh konsumsi zat gizi pada masa lampau, bahkan jauh sebelum masa itu (Budiyanto, 2002)

\section{METODE}

Tujuan utama penelitian ini bukan hanya sekedar untuk mendeskripsikan objek yang 
diteliti akan tetapi mencakup hubungan antara sosial ekonomi dengan pemahaman gizi yang dimiliki oleh orangtua. Penelitian ini dilakukan dengan menggunakan pendekatan kuantitatif. Menurut Nana Sudjana dan Ibrahim (2001) definisi penelitian kuantitatif adalah penelitian yang didasari pada asumsi, kemudian ditentukan variable, dan selanjutnya dianalisis dengan menggunakan metode-metode penelitian yang valid, terutama dalam penelitian kuantitatif.

Teknik analisis data pada penelitian ini menggunakan korelasi pearson, yakni suatu penelitian untuk mengetahui hubungan dan tingkat hubungan antara dua variable atau lebih tanpa ada upaya untuk mempengaruhi variable tersebut sehingga tidak terdapat manipulasi variable (Faenkel dan Wallen, 2008;328).

Dalam penyusunan instrumen atau pengumpulan data mengacu pada angket profil orangtua dan angket pemahaman Gizi Orangtua, dan analisis yang digunakan ialah korelasi pearson dengan Tingkat Sosial Ekonomi sebagai variable $\mathrm{X}$ dan Pemahaman Gizi Orangtua sebagai variable Y. cara dalam menganalisa data ialah dengan pernyataan-pernyataan yang ditujukan kepada responden

Lokasi penelitian berada di TK Alishlah Ngale yang beralamat di Dusun Ngale RT 010 RW 001 Desa Ngale Kecamatan Paron Kabupaten Ngawi. Orangtua dari daerah tersebut dipilih dalam pengambilan sampel pemahaman gizi orangtua dikarenakan kerberagaman tingkat sosial ekonomi. Jenis penelitian ini merupakan penelitian korelasional dengan menggunakan instrumen penelitian berupa angket yang diisi oleh 30 wali murid sebagai responden.

\section{HASIL DAN PEMBAHASAN Hasil}

Penelitian kuantitatif untuk mengetahui hubungan tingkat sosial ekonomi dengan pemahaman gizi orangtua di TK Al-Ishlah Desa Ngale Kecamatan Kabupaten Ngawi, menunjukkan bahwa mayoritas orangtua murid memiliki latar belakang pendidikan SMA/SMK, hal ini ditunjukkan dengan hasil presentase sebesar $66.7 \%$ dari seluruh responden yang ada di TK Al-Ishlah Ngale. Sedang untuk lulusan terbanyak setelah SMA/SMK adalah lulusan Perguruan Tinggi yaitu sebesar $20 \%$ hal ini mengindikasi tingkat kesadaran orantgua dalam hal pendidikan cukup baik. Sedang untuk latar pendidikan yang lain yaitu SMP dan SD masingmasing sebanyak $6,7 \%$.

Dalam menentukan tingkat sosial ekonomi disamping dari latar belakang pendidikan orangtua, juga dapat ditentukan dari pekerjaan orangtua. Dari responden di TK Al-Ishlah Ngale pekerjaan terbanyak dari wali murid adalah Mengurus Rumah Tangga yang mencapai $66,7 \%$ dari keseluruhan responden, sedang pekerjaan lain yaitu swasta dan wiraswasta yang sama-sama mencapai $16,7 \quad \%$ dari keseluruhan responden. 


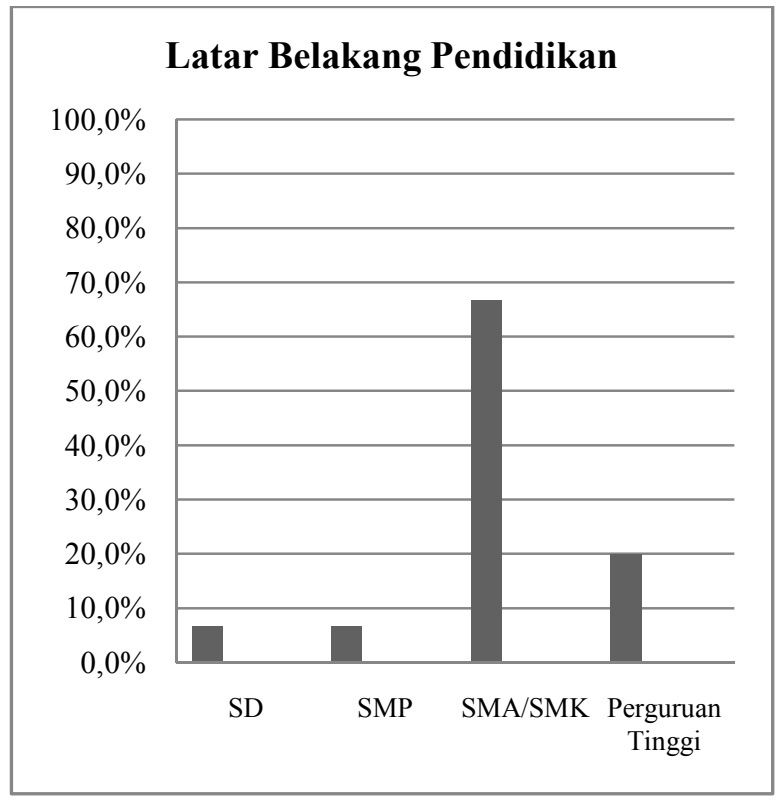

TINGKAT SOSIAL EKONOMI

Berdasarkan penelitian yang telah dilakukan menunjukkan bahwa $86,7 \%$ dari 30 responden yaitu wali murid di TK-Al ishlah termasuk dalam kategori tingkat ekonomi mampu sedangkan 13,3\% dalam kategori tingkat ekonomi sangat mampu.

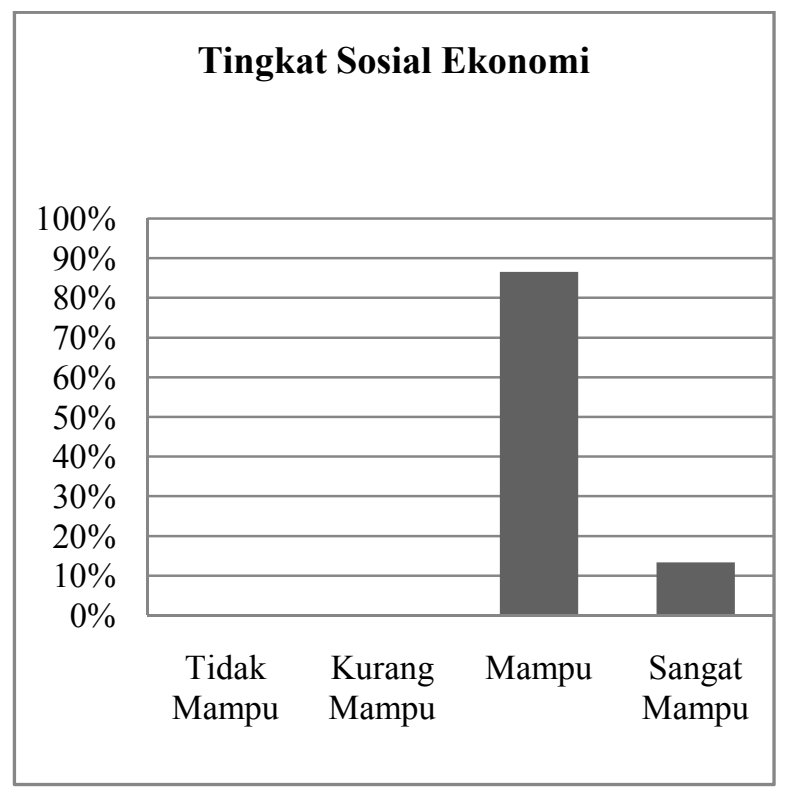

\section{Pemahaman Gizi Orangtua}

Berdasarkan penelitian yang telah dilakukan bahwa $46,7 \%$ dari 30 responden wali murid di TK Al-Ishlah Ngale masuk dalam kategori Paham Gizi anak sedangkan
53,3\% masuk dalam kategori Sangat Paham terhadap gizi anak

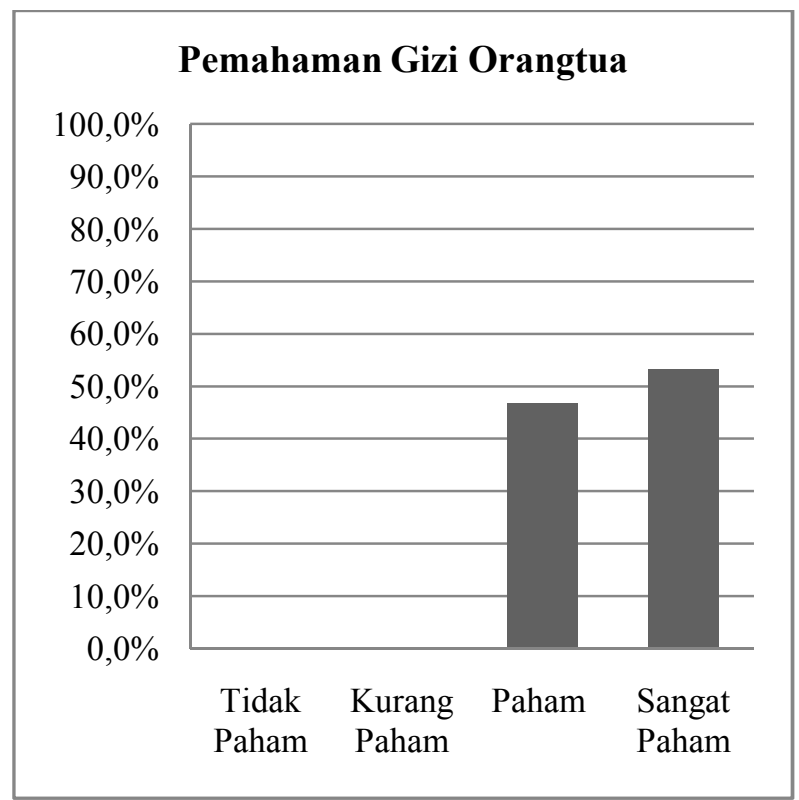

\section{Hubungan Tingkat Sosial Ekonomi Dengan Pemahaman Gizi Orangtua}

Berdasarkan dari hasil penelitian dan perhitungan SPSS, penelitian mengenai Hubungan Tingkat Sosial Ekonomi dengan Pemahaman Gizi Orangtua di TK Al-Ishlah memiliki hubungan yang sangat lemah hal ini selaras dengan interpresi oleh D.A de Vaus dengan hasil perhitungan SPSS dari penelitian ini yang menunjukkan nilai correlation pearson 0,147 dari 30 responden.

\section{Correlations}

\begin{tabular}{|l|r|r|}
\hline & \multicolumn{1}{|c|}{ X } & \multicolumn{1}{c|}{ y } \\
\hline x Pearson Correlation & 1 & -.147 \\
Sig. (2-tailed) & & .440 \\
N & 30 & 30 \\
\hline y Pearson Correlation & -.147 & 1 \\
Sig. (2-tailed) & .440 & \\
N & 30 & 30 \\
\hline
\end{tabular}




\section{Pembahasan}

Berdasarkan hasil diatas menunjukkan bahwa sebagian besar orangtua di TK Al-Ishlah memiliki latar belakang pendidikan SMA/SMK. Hal ini menunjukkan bahwa latar belakang pendidikan berhubungan dengan pemahaman gizi orangtua. Berdasarkan hasil diatas menunjukkan bahwa mayoritas tingkat sosial ekonomi dalam kategori mampu. Berdasarkan hasil diatas menunjukkan bahwa mayoritas orangtua di TK Al-Ishlah Ngale dalam kategori sangat paham terhadap gizi anak. Dalam mayoritas masyarakat beranggapan bahwa semakin tinggi latar belakang pendidikan semakin paham dalam masalah gizi oleh orangtua. Namun sepertinya hal ini kurang sejalan dengan hasil penelitian yang berjudul "Hubungan Tingkat Sosial Ekonomi terhadap Pemahaman Gizi Orangtua”.

Dalam penelitian ini menunjukkan bahwa hubungan tingkat sosial ekonomi dengan pemahaman gizi orang tua oleh wali murid di TK Al-Ishlah sangat lemah namun tingkat pemahaman orangtua terhadap gizi anak mayoritas sangat paham hal ini dapat terjadi dikarenakan oleh faktor-faktor lain. Contonhnya adalah literasi digital yakni literasi digital merupakan kemampuan dan keterampilan dalam mengatur sebuah informasi dalam dunia digital yang didukung oleh keterampilan dalam pengoperasian perangkat digital yang ada (Laksono et al., 2019). Misalnya pada masa modern seperti ini walimurid dapat mudah mengakses jaringan internet dan sosial media sehingga informasi dapat dengan mudah didapat tak terkecuali mengenai gizi anak. Selain itu juga faktor gencarnya sosialisasi ditingkat posyandu desa juga berperan dalam meningkatkan pemahaman orangtua mengenai gizi anak

\section{PENUTUP}

\section{Kesimpulan}

Dari hasil analisis yang dilakukan bersumber dari data yang diperoleh dalam penelitian, maka dapat diambil kesimpulan sebagai berikut: terdapat hubungan yang sangat lemah antara Tingkat Sosial Ekonomi sebagai Variabel $\mathrm{X}$ dan Pemahaman Gizi Orangtua sebagai Variabel Y. Selain itu dari hasil analisis penelitian ini belum tentu dengan semakin tingginya tingkat sosial ekonomi orangtua semakin tinggi pula tingkat pemahaman gizi anak oleh orangtua.

\section{Saran}

Penelitian ini masih belum sempurna, karena pada variable Status Sosial Ekonomi masih menggunakan klasifikasi yang sederhana dimana terdapat 4 golongan status sosial ekonomi yaitu golongan Sangat mampu, mampu, kurang mampu dan tidak mampu. Oleh karena itu , bagi peneliti selanjutnya yang hendak meneliti mengenai sosial ekonomi diharapkan dapat menggunakan klasifikasi yang lebih menyeluruh dimana terdapat enam golongan masyarakat yaitu upper-upper class, lower-upper class, upper-middle class, lower-middle class, upper-lower class, dan lower-lower class.

\section{DAFTAR PUSTAKA}

Budiyanto, M.A.K., 2002. Dasar-dasar Ilmu Gizi. Malang: UMM Press

Frankel, J.P and Wallen N.E. 2008. How To Design and Evaluate Research in Education. New York: Mc. Graw Hill Companies. Inc. 
John W. Santrock. 2007. Perkembangan

Anak Jilid I Edisi Kesebelas. Jakarta:

PT Erlangga

Laksono, B. A., Supriyono, S., \& Wahyuni, S. (2019). Literasi Finansial Dan Digital Keluarga Pekerja Migran Ditinjau Dari Latar Belakang Pendidikan. Jurnal Pendidikan Dan Kebudayaan, 4(2), 139-151. https://doi.org/10.24832/jpnk.v4i2.129 1

Myers, D. G. 1983. Social Psychology. New York: Mc. Graw. Hill Inc

Slavastoga, Karee. 1989. Diferensiasi Sosial. Jakarta: PT Bina Aksara

Sudjana, Nana dan Ibrahim. 2001. Penelitian dan Penilaian Pendidikan. Bandung: Sinar Baru Algesindo 